\section{PARENTS ROLE IN GROWING AN INTEREST IN READING}

\author{
PERANAN ORANG TUA DALAM \\ MENUMBUHKAN MINAT MEMBACA \\ ANAK
}

Jurnal Pendidikan Luar Sekolah

http://kolokium.ppj.unp.ac.id/

Jurusan Pendidikan Luar Sekolah

Fakultas IImu Pendidikan

Universitas Negeri Padang

Sumatera Barat, Indonesia

Volume 9, Nomor 1, 2021

DOI: $10.24036 /$ kolokium-pls.v9i1.456

Received 07 Maret 2021

Approved 11 April 2021

Published 22 April 2021

\author{
Siti Syifa Nuragung Prayiti', Dadang Danugiri² \\ ${ }^{1}$ Universitas Singaperbangsa Karawang \\ ${ }^{2}$ Universitas Singaperbangsa Karawang \\ 3SitiSyifaNP@gmail.com
}

\begin{abstract}
This research are aiming to describe how the role of parents in fostering children's reading interest in Anggrek Early Childhood Education Adiarsa Timur and children's reading interest in Anggrek Early Childhood Education Adiarsa Timur. This research uses a qualitative approach with a case study method. This research was conducted in Anggrek Early Childhood Education Adiarsa Timur. The subject of the research is the source od information consisting of three parents of student, and the source of infomant consisting of one principal and one educator. Determination of research subjects using porposive sampling techniques. Research data obtained through observation, interviews, documentation studies, and triangulation. The research stages consist of orientation phase, exploration stage, and member check stage. Data analysis consists of data collection, data reduction, data display, and final conclusions. The result of research showed that parents have an important role as the first and foremost educator in fostering children's interest in reading early on. The thing that parents can do at home is to give an example to children that reading is important, give special time to read together, and buy books that children love with reading materials that are appropriate to the age of the child. And the children's interest in reading in Pre-school Anggrek Adiarsa Timur is very high, students in Anggrek Early Childhood Education Adiarsa Timur have a high sense of curiosity which makes them eager to learn to read. High interest needs support from several aspects such as learning resources, learning environment, dan learning facilities. Developed intererst will greatly influence behavior not only during the childhood period, but also afterwards, because it is very important for parents to foster children's interest in reading early on.
\end{abstract}

Keywords: The role of parents, Interest in reading, Early Childhood Education

\begin{abstract}
ABSTRAK
Penelitian ini bertujuan untuk mendeskripsikan bagaimana peran orang tua dalam menumbuhkan minat baca anak di PAUD Anggrek Adiarsa Timur dan minat baca anak di PAUD Anggrek Adiarsa Timur. Penelitian ini menggunakan pendekatan kualitatif dengan metode studi kasus. Penelitian ini dilakukan di PAUD Anggrek Adiarsa Timur. Subyek penelitian adalah sumber informasi yang terdiri dari tiga orang tua siswa, dan sumber informasi yang terdiri dari satu kepala sekolah dan satu orang pendidik. Penentuan subjek penelitian menggunakan teknik porposive sampling. Data penelitian diperoleh melalui observasi, wawancara, studi dokumentasi, dan triangulasi. Tahapan penelitian terdiri dari tahap orientasi, tahap eksplorasi, dan tahap member check. Analisis data terdiri dari pengumpulan
\end{abstract}


data, reduksi data, penyajian data, dan kesimpulan akhir. Hasil penelitian menunjukkan bahwa orang tua memiliki peran penting sebagai pendidik pertama dan utama dalam menumbuhkan minat baca anak sejak dini. Hal yang dapat dilakukan orang tua di rumah adalah memberikan contoh kepada anak bahwa membaca itu penting, memberikan waktu khusus untuk membaca bersama, dan membelikan buku yang disukai anak dengan bahan bacaan yang sesuai dengan usia anak. Dan minat baca anak-anak di PAUD Anggrek Adiarsa Timur sangat tinggi, siswa PAUD Anggrek Adiarsa Timur memiliki rasa ingin tahu yang tinggi yang membuat mereka bersemangat untuk belajar membaca. Minat yang tinggi memerlukan dukungan dari beberapa aspek seperti sumber belajar, lingkungan belajar, dan fasilitas belajar. Minat yang berkembang akan sangat mempengaruhi perilaku tidak hanya pada masa kanakkanak, tetapi juga setelahnya, karena sangat penting bagi orang tua untuk menumbuhkan minat baca anak sejak dini.

Kata Kunci: Peran Orang Tua, Minat Membaca, Pendidikan Anak Usia Dini

\section{PENDAHULUAN}

Kegiatan pendidikan adalah serangkaian proses pendidikan yang dilakukan secara terencana untuk mencapai hasil belajar. Pendidikan Anak Usia Dini (PAUD) adalah salah satu upaya pembinaan yang ditunjukkan kepada anak sejak usia dini yang dilakukan melalui pemberian rangsangan pendidikan untuk membantu pertumbuhan dan perkembangan jasmani dan rohani agar anak memiliki kesiapan dalam memasuki pendidikan dasar dan kehidupan tahap berikutnya.

Dalam pemberian rangsangan tersebut, lingkungan dalam keluarga juga berperan penting dalam mendukung perkembangan anak, karena keluarga sebagai pranata, pendidikan pertama dan utama bagi pendidikan anak. Dalam keluargalah kehidupan anak khususnya pada anak usia dini lebih banyak berada. Oleh sebab itu, keluarga atau orang tua harus mengetahui betapa pentingnya memberikan pendidikan pada anak sejak usia dini.

Begitu pula dengan minat membaca anak, keluarga atau orang tua memiliki peranan penting dalam menumbuhkan minat membaca anak. Minat membaca anak dipengaruhi oleh sikap orang tua dalam memberikan pola asuh kepada anaknya di rumah. Salah satu upaya yang dapat dilakukan oleh orang tua di lingkungan keluarga untuk menumbuhkan minat membaca anak yaitu dengan membiasakan anak untuk membaca sejak usia dini.

Jika sejak usia dini anak-anak dikenalkan dengan bahan bacaan dan kebiasaan membaca, maka membaca di masa anak-anak ini akan terus terbawa hingga anak tumbuh dewasa. Orang tua membiasakan anak untuk membaca, memberikan contoh kebiasaan membaca, bahkan mengajarkan anak membaca, serta mewajibkan anak memiliki jadwal khusus untuk membaca dan mengisi waktu luangnya untuk membaca buku. Kebiasaan membaca orangtua akan menjadi inspirasi bagi anak untuk ditiru, karena anak mengganggap orangtua adalah tokoh idolanya.

Kebiasaan membaca yang ditanamkan oleh orang tua kepada anak sejak usia dini sangat berpengaruh bagi anak. Sebab tanpa kebiasaan tersebut anak tidak akan mempunyai kebiasaan membaca yang baik dan rutin bahkan tidak suka membaca, selain itu tidak dapat berprestasi. Dukungan orang tua terhadap kebiasaan membaca tersebut adalah dukungan yang dinyatakan lewat perhatian, nasehat atau teguran. Tujuannnya untuk melatih dan membimbing anak agar terus membaca dan bisa berprestasi di sekolah. 
Dalam hal ini yang paling berpengaruh untuk menumbuhkan minat baca pada anak adalah keluarga. Sejauh ini jika diperhatikan, banyak orang tua yang anak-anaknya dalam pertumbuhan hanya berupaya mengarahkan anaknya bisa membaca lebih dini tapi tidak dalam konteks gemar membaca. Apalagi ketika anak-anak sudah bisa membaca, kenyataannya mereka tidak diarahkan membaca sebagai suatu kebutuhan yang harus dilakukan setiap waktu. Orang tua selayaknya mempunyai cara dan memberikan teladan agar kegiatan membaca dapat dilakukan sejak dini, secara rutin dan menyenangkan. Karena rutinitas yang dilakukan sejak dini pada akhirnya akan menjadi sebuah kebiasaan.

Berdasarkan uraian diatas, penulis terdorong untuk mengadakan penelitian dengan judul "Peranan Orang Tua Dalam Menumbuhkan Minat Membaca Anak Di PAUD Anggrek Adiarsa Timur".

Dalam penelitian ini, peneliti mengambil rumusan masalah "Bagaimana peranan orang tua dalam menumbuhkan minat membaca anak di PAUD Anggrek Adiarsa Timur?”.

Tujuan dari penelitian ini adalah untuk Untuk mendeskripsikan bagaimana peranan orang tua dalam menumbuhkan minat membaca anak di PAUD Anggrek Adiarsa Timur dan untuk mendeskripsikan minat membaca anak di PAUD Anggrek Adiarsa Timur.

\section{METODE}

Penelitian ini menggunakan pendekatan kualitatif dengan metode studi kasus. Subjek penelitiannya adalah sumber informasi yang terdiri dari tiga orang dari orang tua peserta didik, dan sumber informan yang terdiri dari satu orang kepala sekolah dan satu orang pendidik. Penentuan subjek menggunakan teknik purposive sampling. Data penelitian diperoleh melalui observasi, wawancara, dokumentasi dan triangulasi. Tahap-tahap penelitian menggunakan tahap orientasi, tahap eksplorasi, dan tahap member check. Analisis data menggunakan pengumpulan data, reduksi data, display data, dan kesimpulan akhir.

\section{PEMBAHASAN}

PAUD Anggrek berada di wilayah Babakan Tengah Rt 01 Rw 05, Desa Adiarsa Timur, Kecamatan Karawang Timur, Kabupaten Karawang. PAUD Anggrek terletak tidak terlalu jauh dari jalan raya, dekat dengan pemukiman warga, berada di lingkungan Kantor Dinas Pendidikan Pemuda dan Olahraga, Kantor Pendidikan dan Kebudayaan, Kantor Dinas Pemberdayaan Masyarakat Desa, KUA Kec. Karawang Timur, dan Kantor Kelurahan Adiarsa Timur.

\section{Peranan Orang Tua dalam Menumbuhkan Minat Membaca Anak di PAUD Anggrek Adiarsa Timur}

Berdasarkan hasil observasi, wawancara dan studi dokumentasi, didapatkan hasil bahwa orang tua memiliki peran penting dalam memberikan pendidikan kepada anak sejak dini. Dapat dikatakan bahwa orang tua memiliki pengaruh terhadap perkembangan anak, jika orang tua bersikap acuh maka akan berdampak pada perkembangan anak dari berbagai aspek. Hal ini dikemukakan oleh Freud dalam Helmawati yang mengatakan bahwa pengaruh lingkungan keluarga terhadap perkembangan anak merupakan titik tolak perkembangan kemampuan atau ketidakmampuan penyesuaian sosial anak. Karena setiap orang tua pasti 
menginginkan keberhasilan dalam perkembangan pendidikan anaknya. (Helmawati, 2016: 49).

Orang tua memiliki pengaruh terhadap perkembangan anak dalam berbagai peran, dalam belajar atau bersosialisasi, seperti perkembangan anak dalam membaca, jika orang tua tidak menumbuhkan minat anak untuk membaca sedini mungkin, suatu saat anak akan merasa dipaksa untuk melakukan sesuatu yang tidak ingin dilakukannya. Namun, jika orang tua peduli terhadap perkembangan anaknya, orang tua akan berusaha untuk memberikan yang terbaik untuk anaknya.

Dan para orang tualah yang mesti berperan sebagai "guru" di rumah bagi anak-anak. Orang tualah yang paling bertanggung jawab terhadap perkembangan anak, orang tua pula yang paling berkepentingan untuk melakukan apa saja yang bisa dilakukan demi anak-anak. anak-anak harus diajari sejak sangat dini dengan melalui proses mengkondisikan secara halus untuk akrab dan kemudian terbiasa dengan kegiatan membaca.

Untuk menunjang perkembangan anak, dibutuhkan dukungan dari lingkungan keluarga, dalam hal ini orang tua memiliki kewajiban dan tanggung jawab untuk menyediakan lingkungan yang baik untuk mendukung anaknya dalam belajar. Seperti yang telah dijelaskan sebelumnya, bahwa orang tua memiliki peran sebagai pendidik, pendorong, panutan, teman, pengawas, dan konselor. Sebagaimana yang dijelaskan dalam bahwa orang tua memiliki peran sebagai pendidik, pendorong, panutan, teman, pengawas, dan konselor (BKKBN, 2012).

Namun, sebagai orang tua, juga tidak dibenarkan untuk memaksakan kehendak terhadap anak, agar tidak terjadi penolakan dari anak, dan itu merupakan peran orang tua sebagai teman dan konselor. Hal ini di jelaskan oleh Ya'kub Asy-Syaruni dalam Wahyudin (2003: 70), yang mengatakan agar orang tua tidak memaksa anak di bawah umur, tetapi persiapkanlah mental dan kegemarannya membaca. Mendidik anak tanpa di dahului persiapan akan mudah terjadi kesalahan.

Pembenihan tradisi membaca mutlak perlu dilakukan sedini mungkin, sebelum masalah-masalah dan kesulitan menanamkan tradisi membaca yang dihadapi makin parah sejalan dengan makin bertambahnya umur anak (Muktiono, 2003: 12).

Tujuan orang tua dalam menumbuhkan minat membaca anak adalah mempersiapkan anak untuk memasuki jenjang pendidikan dasar. Anak dikenalkan dengan huruf, kosa kata, berlatih berbicara dan dibiasakan untuk membaca sejak dini agar anak dapat membiasakan diri untuk membaca. Anak yang dibiasakan untuk membaca sejak dini, memiliki pengalaman dan pengetahuan yang lebih dibandingkan anak yang tidak dibiasakan untuk membaca.

Dari hasil penelitian yang dilakukan dapat diketahui upaya yang dapat dilakukan orang tua dalam menumbuhkan minat membaca anak adalah dengan memberikan contoh kepada anak bahwa membaca merupakan kegiatan yang menyenangkan, menyediakan buku yang disukai anak, atau membaca bersama anak di waktu senggang. Dapat juga dengan membimbing anak membaca sebelum berangkat atau sepulang anak dari sekolah, bisa juga dengan mendengarkan anak bercerita, dengan begitu anak akan memiliki pemikiran bahwa membaca adalah hal yang menyenangkan.

Hal ini seperti yang telah dijelaskan oleh Muktiono (2003: 31-33), yang menyebutkan beberapa langkah yang dapat di lakukan orang tua dalam menumbuhkan minat membaca anak, yaitu: (1)Menyediakan selalu buku-buku ditempat anak kita biasa bermain; 
(2)Membiasakan untuk membacakan buku kepada anak; (3) Janganlah bosan jika anak minta diceritakan atau dibacakan buku yang sama terus-menerus; (4) Ceritakan dengan bahasa anak; (5) Perankan tiap tokohnya dengan baik; (6) Jangan putus asa jika anak belum menunjukkan perhatian terhadap buku atau cerita yang kita baca; (7) Perlihatkan gambar-gambar penuh warna menarik pada saat membacakan buku; (8) Janganlah menolak jika anak minta dibacakan buku atau didongengkan cerita.

Selain itu, orang tua juga bisa menyediakan waktu untuk membaca bersama, membacakan buku sebelum tidur, dengan begitu hubungan antara orang tua dan anak akan terjalin dengan baik. Membacakan buku bersama anak adalah salah satu hal yang paling berharga yang dapat orang tua lakukan untuk anak, dan membaca bersama anak merupakan ungkapan cinta orang tua kepada anak

\section{Minat Membaca Anak di PAUD Anggrek Adiarsa Timur}

Berdasarkan hasil observasi dan wawancara yang dilakukan, diketahui bahwa minat membaca anak di PAUD Anggrek Adiarsa Timur cukup antusias. Karena menggunakan metode bermain sambil belajar, dengan metode ini anak-anak akan merasa senang dalam belajar membaca, dan anak tidak merasa dipaksakan untuk belajar, dengan begitu anak akan senantiasa dengan hati yang tulus, mau untuk belajar membaca.

Bermain merupakan pendekatan belajar anak usia dini. Melalui bermain, anak diajak untuk bereksplorasi, menemukan, memanfaatkan benda-benda yang ada di sekitarnya, mengekspresikan perasaan, berkreasi, belajar secara menyenangkan dan mengambil kesimpulan mengenai benda di sekitarnya (Modul PP-PAUD dan Dikmas Jawa Barat, 2017: $1.31-1.34)$.

Berkaitan dengan pemberian kesempatan pada anak untuk bermain, karena pada hakikatnya bermain merupakan hak anak sepanjang rentang kehidupannya. Secara intelektual, bermain memungkinkan anak untuk menyerap informasi baru dan membentuk informasi sesuai dengan apa yang diketahuinya. Melalui kergiatan bermain, anak akan mengeksplorasi dunianya, membangun pengetahuanya sendiri, berlatih kepekaan, meningkatkan cara berpikir dan mengembangkan kreativitas. Maka dapat disimpulkan bahwa bermain adalah suatu kebutuhan bagi anak, dengan merancang pembelajaran untuk dilakukan sambil bermain, maka anak belajar sesuai dengan tuntutan taraf perkembangannya.

Minat yang dikembangkan sangat mempengaruhi perilaku tidak saja selama periode masa anak-anak tetapi juga sesudahnya. Itulah sebabnya mengapa perkembangan minat yang bermanfaat dan penting sesuai dengan kemampuan dan kebutuhan anak sering diabaikan. Banyak orang tua dan pendidik merasa bahwa sebagian besar minat kekanak-kanakan hanyalah suatu tingkah saja, yang segera berlalu. Akhirnya, anak cenderung memandang enteng dan menganggap bahwa anak akan "mengakhiri" minat-minat ini dengan bertambahnya usia dan bertambah luasnya pengalaman (Hurlock, 1980: 166).

Adapula faktor yang mempengaruhi minat seseorang, menurut Hurlock dalam Rahmanto (2011: 18) diantaranya: (1) faktor internal, yang terdiri dari faktor jasmaniah, kematangan fisik maupun psikis, dan faktor fisiologis yang bersifat bawaan maupun herediti; dan (2) faktor eksternal, yang terdiri dari faktor sosial meliputi lingkungan keluarga dan sekolah, faktor budaya seperti adat istiadat, ilmu pengetahuan dan teknologi, faktor lingkungan fisik seperti fasilitas rumah, iklim, dan faktor spiritual. 
Motivasi dan dorongan dalam membaca tak jarang ditimbulkan oleh adanya kebiasaan dan contoh dari keluarga. Dalam keluargalah minat dan kebiasaan membaca mulai disulut. Jika dalam sebuah keluarga tidak terdapat teladan dalam kegiatan membaca dan mencintai buku, benih-benih kecintaan membaca dalam diri anak-anak akan sulit tumbuh subur.

Menurut Muktiono (2015: 57), bahwa minat adalah kecenderungan yang tetap untuk memperhatikan dan mengenang beberapa kegiatan. Jika anak menaruh perhatian yang tinggi terhadap membaca, maka anak tersebut memiliki minat yang tinggi terhadap kegiatan membaca. Dijelaskan pula bahwa minat besar pengaruhnya terhadap belajar, karena bila bahan pembelajaran yang dipelajari tidak sesuai dengan minat anak, anak tidak akan menaruh perhatian dan belajar dengan sebaik-baiknya.

Karena seperti yang telah dijelaskan oleh Muktiono (2015: 180) bahwa minat tidak dibawa sejak lahir, melainkan diperoleh kemudian. Minat terhadap sesuatu dipelajari dan mempengaruhi belajar selanjutnya serta mempengaruhi penerimaan minat-minat baru. Untuk meningkatkan minat anak sesuatu, dapat menggunakan minat-minat anak yang telah ada.

Membaca bersama teman juga merupakan hal yang menyenangkan untuk dilakukan, dengan suasana yang mendukung, fasilitas yang memadai, minat membaca anak akan semakin tinggi. Sama halnya dengan di rumah, dalam menumbuhkan minat membaca anak, orang tua wajib menciptakan suasana yang mendukung. Dengan membaca bersama, memfasilitasi anak dengan buku bacaan, merupakan contoh cara orang tua menumbuhkan minat membaca anak. Orang tua yang membiasakan anaknya untuk membaca akan mengerti, saat anak membaca bersama orang tua, orang tua akan melihat mata anaknya berbinar, menandakan bahwa orang tuanya adalah pusat dunia anaknya.Ungkapan cinta ini membentuk asosiasi antara anak dan buku. Kata "buku" akan membangkitkan kebahagiaan bagi anak. Meraba, melihat, dan mencium bau buku selamanya berkaitan dengan kehangatan, rasa aman, dan cinta, dengan begitu orang tua telah menyemaikan hubungan cinta sepanjang hayat antara anak dan membaca.

\section{KESIMPULAN}

Dalam keluarga, orang tua sangat berperan dalam kehidupan anak karena sebagian besar waktunya dihabiskan dalam lingkungan keluarga. Orang tua memiliki kewajiban dan tanggung jawab terhadap pendidikan anaknya, termasuk dalam menumbuhkan minat membaca anak dan menciptakan suasana yang sesuai untuk mendukung minat membaca anak. Karena membaca merupakan hal penting bagi setiap manusia. Dan menumbuhkan minat membaca anak juga merupakan ungkapan cinta sepanjang hayat orang tua kepada anaknya.

Orang tua yang memiliki kesadaran akan hal itu akan merasakannya sebagai beban yang diemban sebagai orang tua, karena jika orang tua gagal menumbuhkan minat membaca anak, seterusnya anak akan memiliki pemikiran bahwa membaca merupakan kegiatan yang tidak menyenangkan. Dan sudah menjadi tugas orang tua untuk meluruskan pemikiran tersebut, bahwa membaca merupakan kegiatan yang menyenangkan, dan hal yang menguntungkan.

Tujuan utama orang tua dalam hal pendidikan anaknya adalah membuat anak membaca dan menyukainya. Saat orang tua berhasil membuat anaknya menyukai bacaan, 
orang tua akan merasakan sesuatu yang dapat dibanggakan, seperti rasa bangga sebagai orang tua yang berhasil membuat anaknya suka membaca. Karena anak yang senang membaca merupakan salah satu tujuan orang tua dalam hal pendidikan anaknya.

Anak-anak di masa Golden Age ini merupakan saat yang tepat untuk menumbuhkan minat membaca. Karena saat usia ini adalah ketika anak sedang mencari jati diri, dan minat terhadap sesuatu. Dibutuhkan dukungan dari lingkungan keluarga, lingkungan masyarakat, dan juga lingkungan sekolah. Dan orang tua merupakan dukungan terpenting bagi anak untuk menumbuhkan minatnya, termasuk minat anak terhadap membaca. Memberikan suasana yang cocok untuk belajar, memfasilitasi anak akan buku bacaan merupakan contoh cara orang tua dalam menumbuhkan minat membaca anak.

Minat membaca anak sangat dibutuhkan, bahkan sampai dewasa. Anak yang dibiasakan untuk membaca sejak dini, akan terbiasa hingga dewasa, dan itu merupakan suatu keberhasilan bagi orang tua. Anak yang memiliki minat terhadap membaca, akan memiliki pengalaman, pengetahuan yang luas, dan memiliki rasa cinta terhadap buku. Bahkan anak yang dibiasakan untuk membaca sejak dini memiliki kenangan yang hangat terhadap buku.

Karena minat yang dibentuk pada akhir masa anak-anak, dapat mempengaruhi anak, sebagai berikut; (1) Minat mempengaruhi bentuk dan intensitas cita-cita; (2) Minat dapat dan memang berfungsi sebagai tenaga pendorong yang kuat; (3) Prestasi selalu dipengaruhi oleh jenis dan intensitas minat seseorang; (4) Minat yang terbentuk dalam masa anak-anak sering kali menjadi minat seumur hidup, karena minat menimbulkan kepuasan.

\section{DAFTAR RUJUKAN}

Badan Kependudukan dan Keluarga Berencana Nasional. (2015). Rencana Strategis Badan Kependudukan Dan Keluarga Berencana Nasional. BKKBN.

Farida, Ida. (2001). Peran Keluarga Dalam Menumbuhkan Minat Baca Anak. Al-Maktabah [Online], Vol 3 (2), 8 halaman. Tersedia: http://journal.uinjkt.ac.id/index.php/almaktabah/article/view/1647 [Diakses 28 September 2019].

Helmawati. (2016). Pendidikan Keluarga. Bandung : PT Remaja Rosdakarya.

Hurlock, Elizabet B. (1980). Psikologi Perkembangan : Suatu Pendekatan Sepanjang Rentang Kehidupan. Penerbit Erlangga.

Modul 1 Diklat Dasar Dalam Jaringan (Daring) Bagi Pendidik PAUD. (2017). Konsep Dasar Pendidikan Anak Usia Dini. Bandung: Kemdikbud PP-PAUD dan Dikmas Jawa Barat.

Muktiono, Joko. D. (2003). Aku Cinta Buku Menumbuhkan Minat Membaca pada Anak. Jakarta: PT. Elex Media Komputindo.

Retno, Endang Condro. (2011). Peranan Orang Tua Dalam Mengembangkan Minat Membaca Di Taman Bacaan Satu Sembilan Patangpuluhan Wirobrajan Yogyakarta.

Skripsi PLS FIPUNY: tidak diterbitkan.

Soelaeman, M. I.(1994). Pendidikan Dalam Keluarga. Bandung: CV Alfabeta.

Tampubolon. (1991). Mengembangkan Minat dan Kebiasaan Membaca Pada Anak. Bandung : Penerbit Angkasa. 